\title{
Analisis Home Visit Method dalam Pembelajaran IPS Siswa Kelas V SDN Inpres Tenga di Masa Covid-19
}

\author{
Fajriatunisah $^{1}$, Syahbuddin $^{1, *}$, Rosdiana $^{1}$ \\ ${ }^{1}$ STKIP Taman Siswa Bima \\ *syahbuddin07@gmail.com
}

Artikel Info

$\underline{\text { Tanggal Publikasi }}$

2021-06-30

\section{Kata Kunci}

Home Visit Home Pembelajaran IPS Covid-19

\section{Abstrak}

Penelitian ini bertujuan menganalisis laratbelakang, proses dan kelebihan maupun kekurangan penerapan Home Visit Method dalam pembelajaran IPS siswa kelas V SDN Inpres Tenga di masa Covid-19. Penelitian ini menggunakan metode kualitatif. Pengumpulan data menggunakan teknik observasi, wawancara dan dokumentasi. Teknik sampiling mengunakan Purposive sampling sedangkan keabsahan data menggunakan triangualasi teknik, sumber dan teori. Tahap akhir melakukan analisa data dengan tahap reduksi data, sajian data, menarik kesimpulan dan verifikasi. Hasil penelitian menyimpulkan bahwa penerapan Home Visit Method dalam pembelajaran IPS pada siswa kelas V SDN Inpres Tenga dilatarbelakangi kendala yang ditemukan dalam pembelajaran Daring. Kendala pembelajaran Daring di kelas V SDN Inpres Tenga dimana tidak semua siswa memiliki Smartphone. Hal ini berkaitan dengan kemampuan ekonomi orang tua siswa kelas V SDN Inpres Tenga dimana sebagaian besarnya adalah petani. Pelaksanaan Home Visit Method dalam pembelajaran IPS pada siswa kelas V SDN Inpres Tenga dilaksanakan dengan beberapa tahap: perencanaan, pelaksanaan, evaluasi, tindak lanjut dan menyusun laporan. Kelebihan Home Visit Method dimana guru dapat melihat, mengawasi secara langsung kegiatan belajar peserta didik selama masa pandemi Covid-19 dan dapat menjalin silatuhrahmi yang erat dengan orang tua peserta didik. Kedua, guru bisa berinteraksi langsung dengan siswa terkait materi pembelajaran sehingga terhindar dari miskomunikasi. Kelemahannya, dimana sebagian tidak mengikuti pembelajaran, siswa mengutamakan kegiatan yang lain seperti bermain. Demikian halnya dengan waktu belajar dalam Home Visit Method yang sedikit sehingga sulit menjangkau materi IPS yang laus.

\section{PENDAHULUAN}

Pada awal tahun 2020, dunia dikejutkan dengan mewabahnya suatu penyakit yang disebabkan oleh sebuah virus yang bernama Corona atau dikenal dengan istilah Covid-19 (Coronavirus Disease). Pada tanggal 31 Desember 2019, World Health Organization(WHO) mendapatkan informasi mengenai kasus pneumonia yang terjadi di kota Wuhan, Provinsi Hubei, Cina. Sejak 31 Desember 2019 hingga 3 Januari 2020 kasus ini meningkat pesat, ditandai dengan dilaporkannya sebanyak 44 kasus. Tidak sampai satu bulan, penyakit ini telah menyebar di berbagai provinsi lain di China, Thailand, Jepang, dan Korea Selatan (Susilo, dkk.2020: 45)

Pada tanggal 7 Januari 2020, otoritas Cina mengkonfirmasi telah mengidentifikasi virus baru, yaitu virus Corona, yang merupakan famili virus flu, seperti virus SARS dan MERS, yang mana dilaporkan lebih dari 2.000 kasus infeksi virus tersebut terjadi di Cina, termasuk di luar Provinsi Hubei. Virus Corona (CoV) merupakan famili virus yang menyebabkan penyakit mulai dari flu biasa hingga penyakit yang lebih berat seperti Middle East Respiratory Syndrome (MERS-SoV) dan Severe Acute Respiratory Syndrome (SARS-CoV). Pada 11 Februari 2020, WHO mengumumkan nama virus Corona jenis baru tersebut adalah Corona Virus Disease 2019 (disingkat menjadi Covid-19). 
(https://vivahealth.co.id/article/detail/13439/mengenal-covid-19. Diunduh, Rabu, 18-08-2021 pukul $18: 32)$.

Joaurnal of The Indonesian Society of Respirology volume 40, nomor 2, April 2020 melaporkan bahwa virus ini telah menyebar hingga ke 199 negara. Indonesia melaporkan kasus pertama pada 2 Maret 2020, yang diduga tertular dari orang asing yang berkunjung ke Indonesia. Kasus di Indonesia pun terus bertambah, hingga tanggal 29 Maret 2020 telah terdapat 1.115 kasus dengan kematian mencapai 102 jiwa. Tingkat kematian Indonesia 9\%, termasuk angka kematian tertinggi (Handayani $\mathrm{dkk}, 2020: 121)$.

Perkembangan Covid-19 mempengaruhi berbagai bidang kehidupan terutama pendidikan. Di bidang pendidikan, Menteri Pendidikan dan Kebudayaan pada tanggal 24 Maret 2020 mengeluarkan Surat Edaran (SE) nomor 4 tahun 2020 tentang Pelaksanaan Kebijakan Pendidikan dalam Masa Darurat Penyebaran Coronavirus Disease (Covid-19). Salah satu poin penting yang disampaikan dalam surat edaran di atas bahwa Belajar dari Rumah melalui pembelajaran daring/jarak jauh dilaksanakan untuk memberikan pengalaman belajar yang bermakna bagi siswa, tanpa terbebani tuntutan menuntaskan seluruh capaian kurikulum untuk kenaikan kelas maupun kelulusan. Berdasarkan ketentuan di atas maka pembelajaran Luring dengan tatap muka langsung antara guru dan siswa diganti ke pembelajaran Daring (Dalam Jaringan). Pembelajaran daring dapat dimaknai sebagai suatu kegiatan belajar mengajar yang memanfaatkan jaringan atau koneksi internet sehingga terjalin komunikasi antara pendidik dan peserta didiknya tanpa melibatkan kontak fisik (Loviana \& Baskara 2020: 62).

Namun pembelajaran Daring dirasakan memiliki banyak hambatan misalnya kepemilikan Smartphone, pulsa yang memadai, jariungan internet yang baik, dan kemampuan siswa maupun orang tua mengunakan aplikasi pembelajaran Daring. Hasil penelitian Cintiasih, mahasiswa Pendidikan Guru Madrasah Ibtidaiyah Fakultas Tarbiyah dan Ilmu Keguruan Institut Agama Islam Negeri (IAIN) Salatiga menyimpulkan bahwa faktor penghambat dalam mengimplementasikan pembelajaran daring yaitu kurangnya efektifitas dan efisiensi waktu dikarenakan orang tua siswa yang sibuk dengan pekerjaannya sehingga tidak dapat mendampingi anaknya dalam proses pembelajaran daring, minimnya antusias siswa dalam mengikuti pembelajaran daring yang berdampak pada minimnya pemahaman siswa akan materi yang diberikan oleh guru kepada siswa (Cintiasih, 2020: 65). Demikian halnya hasil penelitian Trisnawati Khusnul Qotimah dari Program Studi Pendidikan Guru Madrasah Ibtidaiyah Fakultas Tarbiyah dan Ilmu Keguruan Institut Agama Islam (IAIN) Negeri Salatiga tahun 2020 yang menyimpulkan bahwa hambatan pembelajaran Daring Guru IPS MI Negeri 4 Sukoharjo Kecamatan Baki Kabupaten Sukoharjo Tahun Pelajaran 2020/2021 adalah faktor teknis yang dialami Bapak/Ibu guru dalam proses pelajaran daring adalah kurang canggihnya HP yang dimiliki orang tua (2020: 64).

Pembelajaran Daring juga membutuhkan biaya yang besar. Naserly, M. K (2020) menyatakan problematika pembelajaran daring yaitu kendala dalam pembiayaan pembelajaran daring. Orangtua siswa mengeluhkan bahwa untuk mengikuti pembelajaran daring, mereka harus mengeluarkan biaya cukup mahal untuk membeli kuota data internet (Sholeh, 2021: 81). Pembelajaran Daring memang membutuhkan biaya yang cukup besar bila dibandingkan dengan pembelajaran Luring. Orang tua harus menyediakan Smartphone, pulsa yang memadai. Di samping itu masalah jaringan internet dimana tidak semua daerah dapat dijangkau terutama di daerah $3 \mathrm{~T}$, Terdepan, Terpencil dan Tertinggal.

Permasalahan-permasalahan di atas menyebabkan banyak sekolah dan guru yang menolek ke pembelajaran Luring. Demikian halnya dengan pembelajaran IPS di kelas V SDN Inpres Tenga di masa Covid-19. Ilmu Pengetahuan Sosial merupakan integrasi dari berbagai cabang ilmu-ilmu sosial seperti, sosiologi, sejarah, geografi, ekonomi, politik, hukum dan sosial budaya. Ilmu Pengetahuan 
Sosial merupakan bagian dari kurikulum sekolah yang diturunkan dari sisi materi cabang-cabang ilmu sosial (Trianto, 2015: 171).

Model pembelajaran yang dipilih adalah Visit Home Method. Visit Home Method adalah kunjungan kerumah peserta didik yang dilakukan untuk membantu menyelesaikan permasalahan peserta didik, dimana kunjungan ini dilakukan dalam rangka mencari tahu lebih lanjut informasi tentang peserta didik (Suhendro, 2020:137). Home Visit semakin dibutuhkan dalam dunia pendidikan yang berperan dalam mencari jalan keluar dari setiap kesulitan yang dihadapi siswa dalam proses belajar Daring.

Hal inilah yang menarik peneliti untuk mengetahui proses pembelajaran IPS di kelas V SDN Inpres Tenga kecamatan Woha kabupaten Bima. Peneliti mengadakan sebuah penelitian yang berjudul Analisis Pembelajaran IPS Siswa Kelas V SDN Inpres Tenga di masa Covid-19. Peneliti akan mengadakan penelitian yang berjudul Analisis Home Visit Method dalam pembelajaran IPS siswa kelas V SDN Inpres Tenga di masa Covid-19.

\section{METODE PENELITIAN}

Penelitian ini menggunakan penelitian metode kualitatif. Penelitian kualitatif menurut Bogdan ES Taylor adalah prosedur penelitian yang menghasilkan data deskriptif berupa kata-kata tertulis atau lisan dari orang-orang dan berprilaku yang dapat diamati yang diarahkan pada latar dan individu secara holistik (utuh) (Gunawan, 2015: 82). Sedangkan Sugiyono (2016: 9) menyatakan bahwa metode penelitian kualitatif adalah metode penelitian yang berlandaskan pada filsafat postpositivisme, digunakan untuk meneliti pada kondisi obyek yang alamiah, (sebagai lawannya adalah eksperimen) di mana peneliti adalah sebagai instrument kunci, Teknik pengumpulan data dilakukan secara triangulasi (gabungan), analisis data bersifat induktif/kualitatif, dan hasil penelitian kualitatif lebih menekankan makna dari pada generalisasi.

Sumber data berasal dari sumber primer dan sekunder. Menurut LOfland sumber data utama dalam penelitian kualitatatif adalah kata-kata dan tindakan selebihnya adalah data tambahan seperti dokumen dan lain-lain (Satori dan Komariah, 2009: 105). Sedangkan teknik pengumpulan data menggunakan teknik observasi, wawancara, studi dokumentasi. Teknik samplingmenggunakan Purposive sampling adalah teknik pengambilan sampel sumber data dengan pertimbangan tertentu, misal orang tersebut dianggap paling tahu tentang apa yang kita harapkan (Sugiyono, 2015: 300). Keabsahan data menggunakan tiga teknik yaitu triangulasi teknik, triangulasi Sumber dan triangulasi teori. Menurut Susan Stainback, tujuan dari triangulasi bukan untuk mencari kebenaran tentang beberapa fenomena, tetapi lebih pada peningkatan pemahaman peneliti terhadap apa yang telah ditemukan (Sugiyono, 2015: 330). Triangulasi teknik adalah menguji kredibilitas data yang dilakukan dengan cara mengecek data kepada sumber yang sama namun dengan teknik yang berbeda (Sugiyono, 2018: 366). Sedangkan triangulasi sumber menurut Patton (dalam Moleong 2012: 330), berarti membandingkan dan mengecek balik derajat kepercayaan suatu informasi yang diperoleh melalui waktu dan alat yang berbeda dalam penelitian kualitatif. Triangulasi teori, dilakukan dengan menggunakan berbagai teori untuk menafsirkan sebuah data. Penggunaan beragam teori dapat membantu memberikan pemahaman yang lebih baik saat menafsirkan data. Tahap terkahir adalah analisis data penelitian. Teknik analisa data melalui tiga langkah yaitu reduiksi data, sajian data dan menarik kesimpulan dan verifikasi. Menurut Sugiyono (2015: 90) analisis penelitian dilakukan sebelum di lapangan dan penelitian yang dilakukan di lapangan. Pada analisis sebelum di lapangan analisis yang dilakukan terhadap data hasil studi pendahuluan atau data sekunder yang akan digunakan untuk menetukan fokus penelitian. 


\section{HASIL DAN PEMBAHASAN}

\section{Latarbelakang penerapan Home Visit Method dalam Pembelajaran IPS Kelas V SDN Inpres Tenga}

Upaya mengantisipasi penyebaran Covid-19, maka pemerintah dalam hal ini Kementerian Pendidikan Nasional mengeluarkan Peraturan Menteri Pendidikan Nasional Republik Indonesia nomor 41 tahun 2007 tentang Standar Proses untuk Satuan Pendidikan Dasar dan Menengah. Dalam ketentuan tersebut ditegaskan dimana satuan pendidikan menerapkan Belajar dari Rumah melalui pembelajaran daring/jarak jauh dilaksanakan untuk memberikan pengalaman belajar yang bermakna bagi siswa, tanpa terbebani tuntutan menuntaskan seluruh capaian kurikulum untuk kenaikan kelas maupun kelulusan. Artinya seluruh satuan pendidikan sejak tanggal 24 Maret 2020 harus menerapkan Belajar dari Rumah (BDR) dengan metode Daring.

Surat edaran Kementerian Pendidikan Nasional ditindaklanjuti oleh Sekretariat Daerah Kabupaten Bima selaku Ketua Harian Satuan Tugas Penanganan Covid-19 Kabupaten Bima mengeluarkan Surat Edaran Nomor 360/002/06.23/2021 tentang Pelaksanaan Pembatasan Kegiatan Masyarakat (PPKM), Pemerintah dan Pendidikan dalam Penanganan Corona Virus Disease 2019 (Covid-19) di Kabupaten Bima pada tanggal 26 Januari 2021. Terkait masalah pendidikan dijelaskan bahwa satuan pendidikan menerapkan belajar dari rumah (BDR) secara Daring (Dalam Jaringan), khusus untuk kelas VI dan IX dilaksanakan secara Luring (Luar Jaringan) dengan menerapkan pola shift.

Namun pembelajaran dengan metode Daring (Dalam Jaringan) menemui banyak kendala baik dari siswa, guru maupun orang tua sendiri. Pembelajaran daring mengharuskan guru, siswa maupun orang tua, mampu menggunakan internet. Kendala pembelajaran Daring di kelas V SDN Inpres Tenga yaitu kemampuan ekonomi orang tua siswa dimana sebagaian besarnya adalah petani sehingga sebagain besar siswa tidak memiliki Smartphone. Dalam pembelajaran Daring, orang tua harus menyediakan Smartphone dengan aplikasi Whats App (WA), aplikasi Zoom, dan dukungan pulsa yang memadai. Hal ini berdampak kurangnya pemahaman siswa dan terhadap penggunaan internet maupun HP dengan aplikasi WA atau Zoom.

Kendala pembelajaran Daring mengharuskan guru, siswa maupun orang tua, mampu menggunakan internet. Kendala yang sangat menghambat pelaksanaan pembelajaran daring terutama di daerah (3T) pinggiran di antaranya adalah minimnya pengetahuan dan keterampilan, serta kemampuan menggunaan internet, koneksi jaringan yang buruk, dan kurangnya fasilitas pembelajaran daring seperti handpone dan kuota internet. Hal ini juga diakui oleh kepala SDN Inpres Bapak J bahwa salah satu kendala pembelajaran Daring adalah tidak semua siswa memiliki Smartphone.

Kendala yang dihadapi guru dalam pembelajaran daring lainnya adalah kurang optimal dalam pencapaian target pembelajaran sesuai kurikulum yang ada. Jurnal Manajemen dan Pendidikan Islam, Vol. 6, No. 2, Desember 2020, menjelaskan bahwa guru Madrasah Tsanawiyah Negeri 1 Kotamobagu memiliki tingkat kesiapan dengan kategori $80,10 \%$ guru siap dalam pelaksanaan home visit dengan respon siswa terhadap program home visit $79,17 \%$ siswa merespon dengan baik, sementara materi pelajaran hanya $65 \%$ yang tersampaikan dari target yang diharapkan dengan presentase target pencapaian hasil belajar 69\% (Mokodompit, 2020: 129).

Hal ini dapat dipahami dimana pembelajaran Luring dapat diterapkan berbagai metode maupun media pembelajaran yang tepat sesuai dengan tujuan dan materi pembelajaran serta teknik evaluasi yang sesuai. Masalah ini disampaikan dalam Jurnal Elementary School, bahwa kendala yang dialami guru selama pembelajaran daring yaitu aplikasi pembelajaran, jaringan internet dan gawai, pengelolaan pembelajaran, penilaian, pengawasan (Rigianti, 2020: 301). 
Mengahadapi kendala di atas guru IPS kelas V SDN Inpres Tenga mengambil solusi yang sesuai dengan keadaan orang tua dan siswa. Solusi yang diambil oleh guru dan sekolah dengan menerapkan Home Visit Method. Menurut istilah home visit adalah kegiatan untuk memperoleh data kemudahan dan komitmen bagi terentaskannya masalah siswa melalui pertemuan dengan orang tua atau keluarganya (Majid, 2017: 193). Home visit atau kunjungan rumah memiliki beberapa tujuan di antaranya untuk memperoleh berbagai keterangan (data) yang diperlukan dalam pemahaman lingkungan dan permasalahan siswa dan untuk pembahasan dan pengentasan masalah siswa (Sukardi, 2008: 92).

Menurut Nahdi (2020:181), Home Visit dapat menjadi alternatif dalam memonitoring perkembangan anak selama di rumah sehingga kegiatan anak dan peran orang tua dalam membimbing anak selama belajar di rumah bisa tercapai. Hal yang sama ditegaskan oleh Mokodompit (2020: 123) dalam Jurnal Manajemen dan Pendidikan Islam, Vol. 6, No. 2, Desember 2020 bahwa Home visit merupakan salah satu solusi mengatasi kesulitan belajar siswa dan merupakan tindakan preventif mengurangi miskomunikasi antara guru dan siswa dalam pembelajaran online.

\section{Pembelajaran IPS Siswa di kelas V SDN Inpres Tenga dengan Home Visit Method}

Berdasarkan hasil wawancara dan studi dokumentasi peneliti bahwa pembelajaran dengan Home Visit Method dilaksanakan dengan tuga tahap yaitu tahap persiapan, pelaksanaan dan evaluasi. Dalam hal ini guru kelas V SDN Impres Tenga Ibu ARF bahwa tahap persiapan pembelajaran Home Visit Method dimana siswa kelas $\mathrm{V}$ yang berjuumlah 26 orang dibagi dalam tiga kelompok. Kelompok A berjumlah 8 orang siswa di dusun Katipu, kelompok B berjumlah 8 orang siswa di dusun Malino dan kelopok C berjumlah 10 orang siswa di dusun Tolo Lembo.

Tabel 1: Pembagian Kelompok Belajar Siswa Kelas V SDN Inpres Tenga

\begin{tabular}{|c|c|c|}
\hline $\begin{array}{c}\text { Nama } \\
\text { Kelompok }\end{array}$ & Nama Siswa & Waktu Kunjungan \\
\hline A & $\begin{array}{ll}\text { 1. } & \text { AF } \\
\text { 2. } & \text { AFP } \\
\text { 3. } & \text { BS } \\
\text { 4. } & \text { BSP } \\
\text { 5. } & \text { DP } \\
\text { 6. } & \text { DRP } \\
\text { 7. } & \text { FS } \\
\text { 8. } & \text { IRP }\end{array}$ & $09: 00-09: 35$ \\
\hline B & $\begin{array}{ll}\text { 1. } & \mathrm{JM} \\
\text { 2. } & \mathrm{MIM} \\
\text { 3. } & \mathrm{IAI} \\
\text { 4. } & \mathrm{MJ} \\
\text { 5. } & \mathrm{MF} \\
\text { 6. } & \mathrm{MS} \\
\text { 7. } & \mathrm{NNG} \\
\text { 8. } & \mathrm{NA} \\
\end{array}$ & $10: 30-11: 05$ \\
\hline $\mathrm{C}$ & \begin{tabular}{|ll} 
1. & $\mathrm{NHF}$ \\
2. & $\mathrm{NH}$ \\
3. & $\mathrm{PW}$ \\
4. & $\mathrm{RA}$ \\
5. & $\mathrm{SN}$ \\
6. & $\mathrm{SSS}$ \\
7. & $\mathrm{YS}$ \\
8. & $\mathrm{MRP}$ \\
9. & $\mathrm{PNS}$ \\
10. & AFN \\
\end{tabular} & $16: 00-16: 35$ \\
\hline
\end{tabular}


Langkah selanjutnya adalah guru kelas menyusun jadwal kunjungan dimana dalam jadwal tersebut ditentukan waktu, tujuan, nama kelompok, materi dan hasil maupun rencana tindak lanjut. Berdasarkan pembagian di atas setiap kelompok memperoleh kunjungan dari guru satu kali sehari, dimana dalam satu hari guru mengujungi ketiga kelompok sekaligus dalam waktu yang berbeda. Kelompok A mendapat jadwal kunjungan pada pagi hari jam 09:00-09:35, kelompok B mendapat kinjungan pada siang hari jam 10:30-11:00, dan kelompok $\mathrm{C}$ mendapat kunjungan pada sore hari jam 16:00-16:35. Selanjunya, guru menginformasikan kepada orang tau peserta didik tentang jadwal belajar dengan metode Home Visit Method. Menurut Ibu ARF pemberitahuan ini agar terjalin komunikasi antara guru, orang tua dan siswa.

Pada saat pelaksanaan menggunakan Home Visit Method guru menggunakan masker dan menjaga jarak pada saat melakukan kegiatan belajar. Kegiatan ini juga dilakukan secara semi formal dimana peserta didik tidak menggunakan pakaian seragam sekolah, adapaun pakaian yang digunakan adalah pakaian sehari-hari yang sopan. Pada hari Senin 21 Juni 2021 jam 09:00 Ibu ARF selaku guru kelas mengujungi kelompok A di dusun Katipu. Kelompok A berjumlah 8 orang siswa namun yang hadir hanya 5 orang siswa.

Pada tahap awal pembelajaran guru mengucap salam dan menanyakan kabar kepada peserta didik, guru juga mengingatkan kepada peserta didik untuk selalu berjaga jarak agar terhindar dari Covid-19. Guru juga menanyakan kepada peserta didik apakah peserta didik sudah sarapan. Pada saat kegiatan terlihat bahwa sebagian peserta didik yang hadir antusias dalam mengikut pembelajaran. Materi pembelajaran IPS yaitu KD 3.4 tentang Peristiwa Kebangsaan Masa Penjajahan. Setelah itu siswa diminta mengerjakan beberapa soal yang serupa dengan pengawasan guru.

Materi selanjutnya, yaitu pembelajaran IPA KD:3.7 tentang Sifat-sifat Benda Padat, Cair, dan Gas. Setelah menyampaikan mareri pembelajaran, guru menanyakan kepada peserta didik tentang sifat-sifat benda yang berada di sekitar kita. Guru mengecek apakah ada yang belum paham dengan materi yang diajarkan dengan melakukan tanya jawab denga peserta didik tentang sifat-sifat benda. Salah satu siswa kelompok A, DRP menjawab pertanyyan guru bahwa salah satu sifat benda padat adalah mempunyaiu bentuk tetap meskipun diletakan pada tempat yang berbeda. Demikian juga dengan pertanyaan sifat benda gas. Salah satu siswa kelompok A, AFP menjawab pertanyaan guru dimana benda gas mempunyai bentuk dan volume sesuai dengan wadahnya.

Kunjungan selanjutnya adalah kelompok B di dusun Malino dengan jumlah sebanyak 8 orang siswa. Perjalanan menuju dusun Malino memakan waktu sekitar 10 menit menggunakan motor. Sedangkan perjalanan dari kelompok B menuju kelompok C memakan waktu sekitar 12 menit. Dalam kegiatan pembelajaran di dua kelompok dimana guru menyampaikan materi yang sama dengan kelompok A. Pelaksanaan pembelajaran dengan menerapkan Home Visit Method pada kunjungan pertama dimana ada beberapa siswa yang belum hadir. Oleh karena itu Ibu ARF berupaya membangun komunikasi dan kerjasama dengan orang tua. Hal ini tidak dapat dipungkiri bahwa peranan orang tua dan guru sangat besat terhadap keberhasilan Home Visit Method. Halam (2017) menjelaskan bahwa keberhasilan dari layanan home visit didukung oleh keterlibatan keluarga dan guru yang professional, mampu berinteraksi langsung secara efektif dengan keluarga dapat meningkatkan motivasi belajar siswa, dari waktu ke waktu akan mengalami perubahan pada hasil belajar siswa (Dwita, dkk. 2018: 3).

Kerjasama antara guru dan orang tua siswa disebut dengan hubungan edukatif. Adanya kerjasama antara orang tua siswa dan guru merupakan bagian dari hubungan edukatif dalam rangka mendidik siswa sehingga siswa dapat memiliki kemampuan akademik dan perilaku yang baik. Hubungan edukatif ini diharapkan dapat mewujudkan persamaan prinsip dalam mendidik siswa sehingga siswa tidak mengalami kesulitan dengan adanya pola pendidikan yang berbeda antara belajar di rumah dan di sekolah (Mokodumpit, 2020: 126). 
Home Visit Method selanjutnya memasuki tahap evaluasi. Evaluasi yang dilakukan untuk menilai suatu program, aktivitas-aktivitas yang dilaksanakan, serta pelaksanaan-pelaksanaannya guna membuat keputusan atau mengambil langkah-langkah tertentu di waktu mendatang. Tahap evaluasi pelaksanaan Home Visit Method, peneliti menggali informasi melalui observasi dan wawancara. Tujuannya untuk mencari tahu kelebihan dan kekurangan atau hambatan baik pada guru siswa maupun orang tua. Dalam tahap ini guru memberikan tugas kepada siswa untuk mengetahui sejauhmana hasil penerapan Home Visit berdampak pada hasil belajar. Tugas tersebut dikerjakan di rumah masing-masing dengan pengawasan orang tua. Oleh karena itu Ibu ARF selaku guru IPS mengkomunikasikan pemberian tugas tersebut kepada orang tua siswa. Tugas tersebut dikumpulkan pada kunjungan berikutnya.

Pada hari Senin 28 Juni 2021 jam 09:00 Ibu ARF selaku guru kelas mengujungi kelompok A di dusun Katipu. Kegiatan pembelajaran IPS dihadiri oleh seluruh siswa kelompok A berjumlah 8 orang siswa. Namun di kelompok B dan C, masih ada siswa yang belum mengukuti pembelajaran IPS. Setelah guru membuka dan menyampaikan materi pembelajaran, siswa dipersilakan mengumpulkan tugas. Hasil pemeriksaan terhadap tugas-tugas siswa, ditemukan beberapa siswa belum memahami materi yang disampaikan. Sebagai langkah tindak lanjut, Ibu ARF menerangkan kembali materi yang dinilai belum dipahami siswa. Setelah itu diulakukan Tanya jawab terkait materi yang disampaikan.

Pelaksanaan Pembelajaran IPS pada siswa kelas V SDN Inpres Tenga dilaporkan secara berkala. Laporan disampaikan kepada kepala SDN Inpres Tenga setelah dua laki pertemuan. Menurut Ibu ARF, hal ini agar permasalahan pelaksanaan pembelajaran dengan Home Visit Method dapat diatasi secepatnya oleh pihak guru, sekolah dengan melibatkan orang tua siswa. Hasil studi dokumentasi terhadap laporan Ibu ARF memuat jadwal kunjungan, kehadiran siswa dan catatan-catatan temuan selama berlangsungnya pembelajaran dengan Home Visit Method.

\section{Kelebihan dan Kekurangan Home Visit Method dalam Pembelajaran IPS pada Siswa Kelas V SDN Inpres Tenga}

Kegiatan Home Visit di masa pandemi saat ini sebagai bentuk kegiatan belajar mengajar dari rumah. Sebuah metode tentu mempunyai kelebihan dan kekurangannya, demikian halnya dengan Home Visit Method. Home Visit Method merupakan kegiatan kunjungan guru ke rumah siswa. Melalui kegiatan ini guru dapat melihat, mengawasi secara langsung kegiatan belajar peserta didik selama masa pandemi Covid-19 dan dapat menjalin silatuhrahmi yang erat dengan orang tua peserta didik. Kedua, guru bisa berinteraksi langsung dengan siswa terkait materi pembelajaran. Interaksi ini dapat menghindari miskomunikasi antara guru dan siswa dalam pembelajaran online. Guru juga dapat berinteraksi langsung dengan prang tua siswa sehingga dapat diajak kerjasama dalam memantau belajar siswa. Kedua hal di atas sulit ditemukan dalam pembelajaran Daring.

Kekurangan Home Visit Method dalam pembelajaran IPS di kelas V SDN Inpres Tenga seperti yang dijelaskan oleh guru wali kelas $\mathrm{V}$ dimana sebagian siswa tidak mengikuti pembelajaran dan mengutamakan kegiatan yang lain seperti bermain. Hal ini dapat kita temukan dalam kelompok B dan kelompok C dimana pada pertemuan kedua masih ada siswa yang belum mengikuti pembelajaran IPS. Kelemahan atau kekurangan lain yang ditemukan adalah masalah waktu belajar dengan Home Visit Method. Berdasarkan jadwal yang disusun dimana waktu pertemuan sekitar 30-35 menit. Dalam rentang waktu yang sangat sedikit sulit dijelaskan materi IPS yang luas. Kondisi ini sejalan dengan hasil penelitian Bernardinus Agus Arswimba dalam Jurnal Selaras, Kajian Bimbingan dan Konseling Serta Psikologi Pendidikan Volume 1, Nomor 2, November 2018. Hasil penelitian ini menyimpulkan bahwa pelaksanaan program home visit di SMPK Santa Maria Malang berada kategori "Mendekati Standar". Hal ini dikarenakan di SMP tersebut hanya 66\% aspek kegiatan home visit yang telah terlaksana dengan baik, setidaknya ada 29\% aspek kegiatan home visit yang dilaksanakan sebagian dan 4\% aspek kegiatan home visit belum terlaksana (Arswimba, 2018: 119). 


\section{KESIMPULAN}

Penerapan Home Visit Method dalam pembelajaran IPS pada siswa kelas V SDN Inpres Tenga dilatarbelakangi kendala yang ditemukan dalam pembelajaran Daring. Kendala pembelajaran Daring di kelas V SDN Inpres Tenga dimana tidak semua siswa memiliki Smartphone. Hal ini berkaitan dengan kemampuan ekonomi orang tua siswa kelas V SDN Inpres Tenga dimana sebagaian besarnya adalah petani. Hal ini membawa dampak siswa dan orang tua khususnya kurang memiliki kemampuan menggunakan Smartphone dalam pembelajaran Daring. Pelaksanaan Home Visit Method dalam pembelajaran IPS pada siswa kelas V SDN Inpres Tenga dilaksanakan dengan beberapa tahap: perencanaan, pelaksanaan, evaluasi, tindak lanjut dan menyusun laporan.

Kelebihan Home Visit Method dimana guru dapat melihat, mengawasi secara langsung kegiatan belajar peserta didik selama masa pandemi Covid-19 dan dapat menjalin silatuhrahmi yang erat dengan orang tua peserta didik. Kedua, guru bisa berinteraksi langsung dengan siswa terkait materi pembelajaran. Interaksi ini dapat menghindari miskomunikasi antara guru dan siswa dalam pembelajaran online. Kelemahannya dimana sebagian tidak mengikuti pembelajaran ini dikarenakan peserta didik mengutamakan kegiatan yang lain seperti bermain. Demikian halnya dengan waktu belajar dalam Home Visit Method yang sedikit sehingga sulit menjangkau materi IPS yang laus.

\section{Daftar Pustaka}

Arswimba, Bernardinus Agus. (2018). Evaluasi Pelaksanaan Home Visit di SMP. Jurnal Selaras. Kajian Bimbingan dan Konseling Serta Psikologi Pendidikan Volume 1, Nomor 2, November 2018 (111 - 120), e-ISSN: 2621-0614/p-ISSN: 2621-0606. Prodi Bimbingan Konseling, Universitas Sanata Dharma.

Cintiasih, Tiara. (2020). Implementasi Model Pembelajaran Daring pada Masa Pandemi Covid-19 di Kelas III SD PTQ Annida Kota Salatiga Tahun Pelajaran 2020. Pendidikan Guru Madrasah Ibtidaiyah Fakultas Tarbiyah dan Ilmu Keguruan Institut Agama Islam Negeri (IAIN) Salatiga.

Gunawan, Imam. (2015). Metode Penelitian Kualitatif : Teori dan Praktik. Jakarta: Bumi Aksara.

Handayani, Diah, dkk. (2020). Penyakit Virus Corona 2019. Jurnal Respirologi Indonesia. volume 40, nomor 2, April 2020. p-ISSN 0853-7704. Jakarta: Departemen Pulmonologi dan Kedokteran Respirasi Fakultas Kedokteran Universitas Indonesia.

https://vivahealth.co.id/article/detail/13439/mengenal-covid-19. Diunduh, Rabu, 18-08-2021 pukul $18: 32$.

Konita Dian Dwita, Ade Irma Anggraeni. Haryadi. (2018). Pengaruh Home Visit Dan Motivasi Belajar terhadap Hasil Belajar Siswa di SDIT Harapan Bunda Purwokerto. Program Pascasarjana Magister Manajemen. Fakultas Ekonomi dan Bisnis Magister Manajemen. Universitas Jenderal Soedirman Purwokerto.

Loviana, S., \& Baskara, W. N. (2020). Dampak pandemi covid-19 pada kesiapan pembelajaran tadris matematika IAIN Metro Lampung. Epsilon, Vol 1(2), 61-70.p-ISSN: 2685-2519 e-ISSN: 2715 6028. https://doi.org/10.1017/CBO9781107415324.004.

Majid, Abdul. (2017U). Strategi Pembelajaran, Bandung:PT Remaja Rosdakarya.

Mendiknas, (2014). Peraturan Menteri Pendidikan Nasional Republik Indonesia nomor 41 tahun 2007 tentang Standar Proses untuk Satuan Pendidikan Dasar dan Menengah.

Moeloeng, Lexy J. (2012). Metodologi Penelitian Kualitatif. Bandung: Remaja Rosdakarya. 
Mokodompit, Intan Safitri. (2020). Home Visit sebagai Refleksi Kurikulum Darurat Covid-19: Kesiapan Guru, Respon Siswa, Materi dan Hasil Belajar di Madrasah Tsanawiyah. Jurnal Manajemen dan Pendidikan Islam, Vol. 6, No. 2, Desember 2020: 119-131. ISSN (Online): 2550-1038. Madrasah Tsanawiyah Negeri 1 Kotamobagu.

Nahdi, K. dkk. (2020). Implementasi Pembelajaran pada Masa Lockdown bagi Lembaga PAUD di Kabupaten Lombok Timur. Jurnal Obsesi : Jurnal Pendidikan Anak Usia Dini, Vol 5(1), 177 186.ISSN: 2549-8959.

Satori, Djam'an \& Aan Komalasari. (2009). Metode Penelitian Kualitatif. Bandung: Alfabeta.

Sholeh, Abdul. (2021). Implementasi Pendekatan Home Visit Upaya Mengatasi Problematika Pembelajaran Daring pada Siswa Sekolah Dasar Di Masa Pandemic Covid-19. Jurnal Bidang Pendidikan Dasar Vol 5 No 1, Januari 2021, pp 80-89. Universitas Nahdlatul Ulama Cirebon, Indonesia.

Sugiyono. (2015). Metode Penelitian Pendidikan Pendekatan Kuantitatif, Kualitatif, dan REDD. Bandung: Alfabeta.

Sugiyono. (2018). Metode Penelitian Pendidikan Pendekatan Kuantitatif, Kualitatif, dan REDD. Bandung: Alfabeta.

Suhendro, E. (2020). Strategi Pembelajaran Pendidikan Anak Usia Dini di Masa Pandemi Covid-19. Jurnal Ilmiah Tumbuh Kembang Anak Usia Dini, Vol 5(3), 133-140. ISSN: 2477-4715. https://doi.org/10.14421/jga.2020.53-05.

Sukardi, Dewa Ketut. (2008), Pengantar Pelaksanaan Program Bimbingan dan Konseling di Sekolah, Edisi Revisi. Jakarta: Rhienka.

Sukardi, Dewa Ketut. (2008). Proses Bimbingan Dan Konseling di Sekolah. Jakarta: Rineka Cipta.

Surat Edaran Dinas Pendidikan, Kebudayaan, Pemuda Dan Olahraga Nomor: 001/ 80 /01.1/B/2021 tanggal 26 Januari 2021 tentang Pelaksanaan Pembatasan Kegiatan Pembelajaran Masa Pandemi Covid-19 di Kabupaten Bima.

Surat Edaran Sekretariat Daerah Kabupaten Bima Nomor 360/002/06.23/2021 tanggal 26 Januari 2021 tentang Pelaksanaan Pembatasan Kegiatan Masyarakat (PPKM), Pemerintah dan Pendidikan dalam Penanganan Corona Virus Disease 2019 (Covid-19) di Kabupaten Bima.

Susilo, Adityo, dkk. (2020). Coronavirus Disease 2019: Tinjauan Literatur Terkini Coronavirus Disease 2019: Review of Current Literatures. Tim Penanganan Kasus pasien dengan Penyakit Infeksi New Emerging dan Re-emerging Disease (PINERE) RSUPN dr. Cipto Mangunkusumo, Jakarta 2Departemen Ilmu Penyakit Dalam Fakultas Kedokteran Universitas Indonesia - RSUPN dr. Cipto Mangunkusumo, Jakarta

Tohirin. 2012. Metode Penelitian Kualitatif dalam Pendidikan dan Bimbingan Konseling. Jakarta: Raja Grafindo Persada. 